\title{
SPEAK NO LAW WITHOUT JUSTICE: EVALUATING THE RETROSPECTIVE FORCE OF DECLARATIONS OF UNCONSTITUTIONALITY WITH SPECIFIC REFERENCE TO QWELANE V SAHRC \& OTHERS $(686 / 2018)$ [2019] ZASCA 167*
}

\author{
by MP Fourie $e^{* *} \&$ Marno Swart***
}
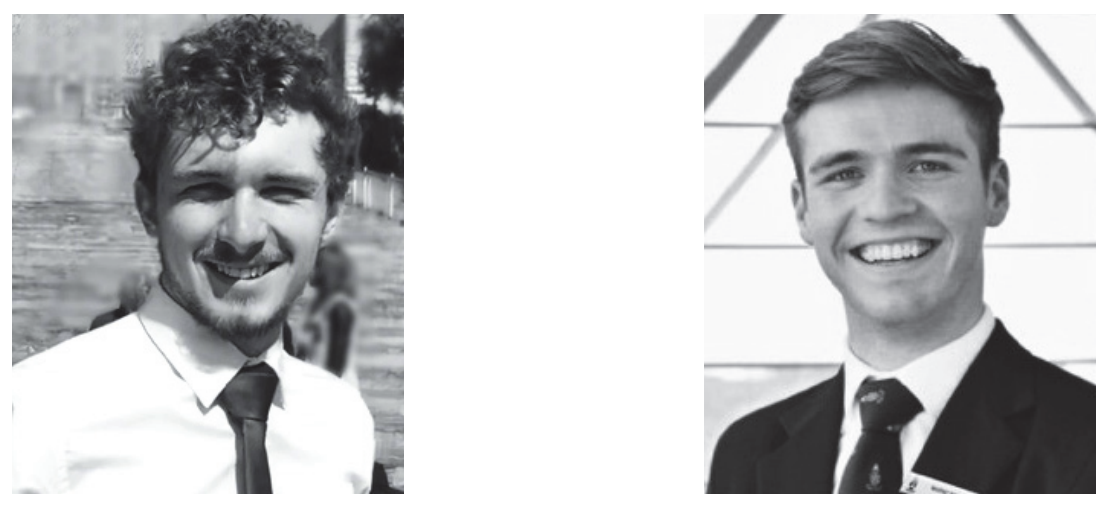

\section{Introduction}

On 29 November 2019 the Supreme Court of Appeal handed down judgment in Qwelane $v$ SAHRC \& Others $^{1}$ (Qwelane) wherein the notorious hate speech prohibition, section 10 of the Promotion of Equality and Prevention of Unfair Discrimination Act $^{2}$ (PEPUDA), was declared unconstitutional and invalid.

This decision, predicted by many and applauded by some, ${ }^{3}$ now awaits confirmation by the Constitutional Court. However, the focus of this article pertains not so much to the merits of the decision in

* We are indebted to Dr Ilze Grobbelaar-du Plessis, senior lecturer in the Department of Public Law, University of Pretoria, for her valuable comments and advice during the writing of this article.

** BCom LLB (penultimate), University of Pretoria. ORCID: 0000-0002-0358-0317.

*** BA LLB (finalist), Assistant Lecturer in the Department of Public Law, University of Pretoria. ORCID: 0000-0001-8863-2923.

$1 \quad(686 / 2018)[2019]$ ZASCA 167.

2 Act 4 of 2000 , hereafter referred to as 'PEPUDA'.

3 See in this regard, inter alia, I Currie \& $\mathrm{J}$ De Waal The Bill of Rights Handbook $\left(6^{\text {th }}\right.$ edition, Juta, 2013) 360; P De Vos \& W Freedman (eds) South African Constitutional Law in Context (Oxford University Press, 2014) 545; JC Botha \& A Govindjee 'Hate Speech Provisions and Provisos: A Response to Marais and 
Qwelane, but to the (possible) retrospective force of this judgment and more broadly to declarations of unconstitutionality and their retrospectivity in general. This article will evaluate whether or not it can be regarded as just and equitable to limit the retrospectivity of the Qwelane decision. This will be done by examining case law of a similar nature and by exploring the array of decisions taken under section 10 of PEPUDA. This inquiry will also consider the possibility of a special judicial arrangement to be made by the Constitutional Court, as well as some practical considerations that have to be regarded such as costs and the applicable procedural law. The arguments put forward are also applicable to future declarations of unconstitutionality.

The task of the courts is rarely easy and their orders often inconvenient; more so where the injustice was caused by the very instrument that was formulated to protect our fundamental rights the law. Yet, the severity of the task at hand should never move our judiciary to speak law without justice. For this purpose the current article will firstly examine the facts of Qwelane and thereafter we will discuss the theoretical underpinning of declarations of unconstitutionality and constitutional changes in this regard. This will be followed by an analysis of case law in which the retrospectivity of declarations of unconstitutionality was significant, whereafter the nature and scope of decisions taken under section 10 of PEPUDA will be evaluated. The injustice of (potentially) limiting the retrospectivity of Qwelane will then be considered and finally, the article will conclude by looking at certain procedural matters.

\section{The matter of Qwelane $v$ SAHRC \& Others}

The appellant in this case, Mr John Dubula Qwelane, is a well-known journalist and was an activist against the white minority government that ruled South Africa prior to $1994 .{ }^{4}$ More than a decade before the judgment in this matter was handed down by the Supreme Court of Appeal, on 20 July 2008, Mr Qwelane authored an article in the Sunday Sun titled 'Call me names - but gay is NOT okay ...'. The offensive part stated:

The real problem, as I see it, is the rapid degradation of values and traditions by the so-called liberal influences of nowadays; you regularly

Pretorius and Proposals for Reform' (2017) Potchefstroomse Elektroniese Regsblad 3; D Davis South African Constitutional Law: The Bill of Rights (LexisNexis, 2019) 11-11; ND Herd 'Should the Flag fit or must we Acquit?' (2019) Pretoria Student Law Review 151 and I Grobbelaar-du Plessis \& K Malan 'Call me names, but does ugly make me hateful? The unjustifiable restriction on freedom of expression under the pretence of combatting hate speech' (2020) Tydskrif vir die Hedendaagse Romeins-Hollandse Reg accepted for publication, article on file with authors.

4 Qwelane (n 1 above) para 4. 
see men kissing other men in public, walking holding hands and shamelessly flaunting what are misleadingly termed their "lifestyle" and "sexual preferences". There could be a few things I could take issue with Zimbabwean President Robert Mugabe, but his unflinching and unapologetic stance over homosexuals is definitely not among those. Why, only this month - you'd better believe this - a man, in a homosexual relationship with another man, gave birth to a child! At least the so-called husband in that relationship hit the jackpot, making me wonder what it is these people have against the natural order of things. And by the way, please tell the Human Rights Commission that I totally refuse to withdraw or apologise for my views... Homosexuals and their backers will call me names, printable and not, for stating as I have always done my serious reservations about their "lifestyle and sexual preferences", but quite frankly I don't give a damn: wrong is wrong! I do pray that someday a bunch of politicians with their heads affixed firmly to their necks will muster the balls to rewrite the constitution of this country, to excise those sections which give licence to men "marrying" other men, and ditto women. Otherwise, at this rate, how soon before some idiot demands to "marry" an animal, and argues that this constitution "allows" it?

Together with the above article appeared a cartoon depicting a man on his knees next to a goat, standing in front of a priest to be married. The caption above the man and the goat reads: 'When human rights meet animal rights'. The text inside a speech balloon attaching to the priest reads: 'I now pronounce you, man and goat.' It was, however, common cause that the appellant was not the creator of the cartoon, nor was his approval obtained before it was published. ${ }^{6}$

The publication was met with huge public outcry, with expressions of outrage and disgust. Following the article, the press ombud received numerous complaints against the appellant and the Sunday Sun. The South African Human Rights Commission (SAHRC), who is the first respondent in this matter, received 350 complaints relating to the article and the cartoon. ${ }^{7}$

The press ombud found the newspaper to be in breach of the South African press code on three counts. Owing to the fact that the Sunday Sun published a poster proclaiming that Mr Qwelane had taken a beating and publishing a page of letters from the public condemning the column, the press ombud held that the newspaper had to some degree made amends. The press ombud ruled that the newspaper should 'complete the amends by publishing an appropriate apology' which was duly published. ${ }^{8}$

In terms of section 20(1)(f) of PEPUDA the SAHRC instituted proceedings against Mr Qwelane in the equality court, alleging that

5 As above.

6 Qwelane (n 1 above) para 5.

7 Qwelane (n 1 above) para 6.

8 Qwelane (n 1 above) para 8. 
his article in the Sunday Sun contravened section 10(1) (read with sections 1, 12, and 11) of PEPUDA. In the trial court, a Magistrates' Court sitting as the equality court, the constitutionality of the legislation could not be tested and Mr Qwelane was ordered to pay damages to the SAHRC. ${ }^{9}$ On application to the Gauteng Local Division of the High Court, before Moshidi J, the Court dismissed Qwelane's constitutional challenge and ruled that the mentioned provisions of PEPUDA were in fact not incompatible with section 16 of the Constitution of the Republic of South Africa, 1996 (the Constitution). ${ }^{10}$

On appeal a full bench of the Supreme Court of Appeal, through the penmanship of Navsa JA, unanimously overturned the decision of the High Court. The Court held that section 10 of PEPUDA could not on any reasonable interpretation be equated with section 16(2)(c) of the Constitution and indicated that it was clear that section 10 extends far beyond the limitation of freedom of expression allowed by section $16 .^{11}$

The order of the Court afforded Parliament a period of eighteen months from the date of judgment (29 November 2019) to remedy the defect of section 10 of PEPUDA. Awaiting amendment(s) to section 10 of PEPUDA by Parliament, section 10 will now read very similar to section $16(2)(c)$ of the Constitution, the court ordering as follows:

10(1) No person may advocate hatred that is based on race, ethnicity, gender, religion or sexual orientation and that constitutes incitement to cause harm.

10(2) Without prejudice to any remedies of a civil nature under this Act, the court may, in accordance with section 21(2)(n) and where appropriate, refer any case dealing with the advocacy of hatred that is based on race, ethnicity, gender, religion or sexual orientation, and that constitutes incitement to cause harm, as contemplated in subsection (1), to the Director of Public Prosecutions having jurisdiction for the institution of criminal proceedings in terms of the common law or relevant legislation. ${ }^{12}$

Interestingly, in paragraph 95 of the judgment, the Court states that ' $[\mathrm{t}]$ he exercise of reading-in so as to provide an interim measure cannot, in terms of the fundamentals of the rule of law, have retrospective effect. 13 This whilst, as will be indicated below, the Constitution itself creates a presumption in favour of retrospectivity. ${ }^{14}$ In line with section $172(2)(a)$ of the Constitution the matter has now been referred to the Constitutional Court for 
confirmation of invalidity, which court date has been set for later in 2020.

As already indicated in the introduction above, the object of this article is not so much to evaluate the specific merits of the decision in Qwelane, especially in the light of the fact that the decision has not yet been confirmed by the Constitutional Court, but rather to examine the retrospective force of declarations of unconstitutionality in general. The facts of Qwelane are, however, tangible and highlight certain topics very well where such orders are to be considered and will thusly serve as a point of reference throughout this article.

\section{Declarations of unconstitutionality}

When the Interim Constitution ${ }^{15}$ came into force on 27 April 1994, the South African judiciary received a complete overhaul. Not only did the South African legislative paradigm shift from one of parliamentary sovereignty to that of constitutional sovereignty, but a new court, the Constitutional Court (of which the status and jurisdiction has changed several times) came to be. ${ }^{16}$ Together with this, all Superior Courts received a new competence, namely the authority to invalidate legislation on grounds of unconstitutionality. ${ }^{17}$

Accordingly, we will assess this novel competence by evaluating the position prior to the constitutional dispensation as well as comparing the provisions of the Interim Constitution with the Constitution, whilst taking into account the most relevant jurisprudence. This is done to illustrate the important shift in the wording of the respective constitutions, and highlight the problem with courts following the precedent set under the Interim Constitution.

\subsection{Courts' competency to invalidate legislation}

As many of the leading cases on declarations of unconstitutionality were decided on the Interim Constitution but the facts in casu were decided on the Constitution, both the provisions of the Interim Constitution and Constitution are applicable. In this regard section 98(5) of the Interim Constitution stated that:

In the event of the Constitutional Court finding that any law or provision thereof is inconsistent with this Constitution, it shall declare such law or provision invalid to the extent of its inconsistency: Provided that the

15 Act 200 of 1993, hereafter referred to as 'the Interim Constitution'.

16 De Vos \& Freedman (n 3 above) 209.

17 Section $98(5)$ of the Interim Constitution and section 172(2)(a) of the Constitution of the Republic of South Africa, 1996 (hereafter 'the Constitution'); De Vos \& Freedman (n 3 above) 209. 
Constitutional Court may, in the interest of justice and good government, require Parliament or any other competent authority, within a period specified by the Court, to correct the defect in the law or provision, which shall then remain in force pending correction or the expiry of the period so specified. ${ }^{18}$

Similarly, the Constitution provides in section 2 that any law or conduct inconsistent with the Constitution is invalid. Furthermore section 172(2)(a) of the Constitution determines that:

The Supreme Court of Appeal, the High Court of South Africa or a court of similar status may make an order concerning the constitutional validity of an Act of Parliament, a provincial Act or any conduct of the President, but an order of constitutional invalidity has no force unless it is confirmed by the Constitutional Court. ${ }^{19}$

Before the advent of our constitutional dispensation, South African courts could only invalidate legislation that had not properly been enacted according to the procedures of the relevant legislature, as well as subordinate legislation deemed to be vague or ultra vires. ${ }^{20}$

\subsection{The doctrine of objective invalidity and retrospective force}

The nature of a declaration of unconstitutionality must be considered, as it informs the reasoning underlying the retrospective power thereof. The South African democracy is inextricably founded on the values of constitutional supremacy and the rule of law. ${ }^{21}$ In the case of Ferreira $v$ Levin $^{22}$ the Constitutional Court held that all law is, objectively, either constitutionally valid or invalid. This, often referred to as the doctrine of objective invalidity, argues that from the inception of the legislation under scrutiny, or the inception of the Interim Constitution (whichever came last), legislation inconsistent with the Constitution has been invalid and without any legal force, to the extent of its inconsistency. ${ }^{23}$ The timing of the court's adjudication on such invalidity is of no inherent consequence. The court's power lies in confirming the invalidity of law, and not in invalidating the law.

Differently put, 'old order legislation', ${ }^{24}$ having been in existence at the enactment of the Interim Constitution on 27 April 1994,

18 Section $98(5)$ of the Interim Constitution.

19 Section 172(2)(a) of the Constitution.

20 CJ Botha Statutory Interpretation: An introduction for students $\left(^{\text {th }}\right.$ edition, Juta, 2012) 67.

21 See above discussion and section 2 of the Constitution.

221996 (2) SA 621 (CC) para 27.

23 De Vos \& Freedman (n 3 above) 394

24 In terms of Schedule 6 of the Constitution this term refers to all legislation enacted before the commencement of the Interim Constitution. Flowing from 'old order legislation' we will use 'new order legislation' to refer to all legislation enacted after the commencement of the Interim Constitution. 
automatically became subject thereto on that date, and all such law inconsistent with the Interim Constitution was from this date objectively invalid, simply awaiting such confirmation by a competent court. As to new order legislation, the Constitution provides for many filters attempting to prevent the enactment of legislation that would not meet constitutional muster. ${ }^{25}$ However, where such legislation is enacted the Court in New National Party of South Africa $v$ Government of South Africa $^{26}$ stated at paragraph 22 that the unconstitutional provision is 'invalid to the extent of its inconsistency with the Constitution, the moment the provision is enacted'.

Both the Interim Constitution and the Constitution have provisions for the retrospective force of declarations of invalidity, however the wording of the sections differ to such an extent that it is worthy of some attention. Section $98(6)$ of the Interim Constitution reads as follows:

Unless the Constitutional Court in the interests of justice and good government orders otherwise, and save to the extent that it so orders (our emphasis), the declaration of invalidity of a law or provision thereof -

(a) existing at the commencement of this Constitution, shall not invalidate (our emphasis) anything done or permitted in terms thereof before the coming into effect of such declaration of invalidity; or

(b) passed after such commencement, shall invalidate (our emphasis) everything done or permitted in terms thereof.

The Interim Constitution thus provided for two different scenarios. Firstly, where old order legislation is declared to be inconsistent with the Interim Constitution having no retrospective force, unless decided to the contrary by the Constitutional Court. Secondly, where new order legislation is found to be inconsistent with the Interim Constitution it will automatically have retrospective force, unless the contrary is decided. ${ }^{27}$ The Constitution in section $172(1)(b)(i)$ states:

When deciding a constitutional matter within its power a court may make an order that is just and equitable, including an order limiting the retrospective effect (our emphasis) of the declaration of invalidity.

In the Constitution no differentiation is drawn between old order legislation and new order legislation and the default position is one of retrospectivity unless ordered to the contrary. ${ }^{28}$ Although not specifically required by the Constitution, but in line with the rules of statutory interpretation and the rule of law, courts seem to be

See in this regard section 79 of the Constitution as well as section 80 , the abstract control by the National Assembly.

261999 (3) SA 191 (CC).

27 National Coalition for Gay and Lesbian Equality v Minister of Justice 1999 (1) SA 6 (CC) paras 83-84.

28 Currie \& De Waal (n 3 above) 189. 
unwilling to grant declarations of invalidity with retrospective force from a date prior to the promulgation of the Interim Constitution in 1994. ${ }^{29}$ This, as Botha argues, is because both the Interim Constitution and the Constitution had no retroactive force. ${ }^{30}$

The objective nature of a law's constitutional validity has important consequences regarding the retrospective power of such a declaration. In National Coalition for Gay and Lesbian Equality v Minister of Justice ${ }^{31}$ Ackermann $\mathrm{J}$ stated that the authority granted to courts to limit the retrospective effect in section 172(1)(b)(i) read with the objective nature established in Ferreira $v$ Levin, ${ }^{32}$ implies an automatic retrospective effect of any declaration of invalidity, despite not being explicitly so stated.

It is pertinent to appreciate that any law found to be inconsistent with the Constitution has always been unconstitutional, and any action flowing from such law is, and has always been, unconstitutional and invalid.

\section{Retrospectivity of declarations of unconstitutionality}

The competency in respect of retrospectivity of declarations of invalidity granted to the court by the Interim Constitution and the Constitution, has been applied in many forms by the Constitutional Court. A discussion of case law wherein the retrospectivity of declarations of invalidity has been applied is thus apposite:

In the case of $S \vee$ Zuma $a^{33}$ the court declared section 217(1)(b)(ii) of the Criminal Procedure $\mathrm{Act}^{34}$ unconstitutional, which placed the burden of proof on an accused person to prove that a confession made to a magistrate was not 'freely and voluntarily' given. ${ }^{35}$ It was held to be inconsistent with section 25 of the Interim Constitution, which, inter alia, provided that an accused person shall have the right to be presumed innocent and to remain silent during trial, as well as the right not to incriminate himself or herself. ${ }^{36}$ The court relied on section 98(6)(a) of the Interim Constitution and held that, generally, a declaration of invalidity of legislation in force at the

See in this regard, inter alia, Ferreira (n 18 above) para 26; National Coalition (n 23 above) para 84 and B Bekink Principles of South African Constitutional Law $\left(2^{\text {nd }}\right.$ edition, LexisNexis, 2016) 117.

30 Botha (n 20 above) 62, for a detailed discussion of the difference between retroactivity and retrospectivity see pages $55-58$.

31 National Coalition (n 27 above) para 84.

32 Ferreira (n 22 above).

331995 (2) SA 642 (CC).

34 Act 51 of 1977.

35 Zuma (n 33 above) para 3.

36 Zuma (n 33 above) para 22. 
commencement of the Interim Constitution does not have retrospective effect unless specifically ordered so by the court (see paragraph 3.2 above). ${ }^{37}$ In order to assess whether the Court should make such an order, the Court considered the possibility of the numerous appeals that would result from such retrospective force. The Court conceded that notice should be given to the possible injustice of previously accused persons, but declared that they could not 'repair all past injustice by a simple stroke of the pen' ${ }^{38}$ In the interest of the administration of justice, the Court gave the order retrospective force only as it pertained to cases in which no verdict had yet been reached. ${ }^{39}$

Heard together with $S \vee$ Zuma, but decided separately, was the case of $S \vee$ Mhlungu. ${ }^{40}$ Herein the Court held that although a presumption against retrospectivity existed based on section 98(6)(a) of the of the Interim Constitution, such a presumption was not inflexible, and was not intended to protect against the invasion of rights. Here, in contrast with Zuma, the declaration of invalidity was given retrospective force from 27 April 1994. ${ }^{41}$

The presumption against retrospectivity in these cases was given concrete form in the case of $S v$ Bhulwana. ${ }^{42}$ Section 21(1)(a)(i) of the Drugs and Drug Trafficking Act, ${ }^{43}$ which placed the burden of proof on any accused found in possession of a certain amount of marijuana to prove that they did not also deal in marijuana, was found to be inconsistent with section 25(3) of the Interim Constitution. When deciding on the retrospectivity of the order, O'Regan J stated that the interests of good government had to be weighed against the interests of individual litigants, as unqualified retrospectivity could lead to 'unnecessary dislocation and uncertainty in the criminal justice process'. 44 She emphatically stated that as a general principle no finalised cases should be affected by the court declaring legislation constitutionally invalid. Instead, O'Regan J gave the order retrospective force as far as it pertains to cases where an appeal or review is pending or where an appeal can still be timeously lodged. ${ }^{45}$ It is thus implied that cases awaiting verdict would also not be bound by the provision that was declared unconstitutional, as in $S \vee$ Zuma.

Of importance is that all three of the above cases were decided under the Interim Constitution and dealt with old order legislation, where section 98(6)(a) explicitly creates the presumption against

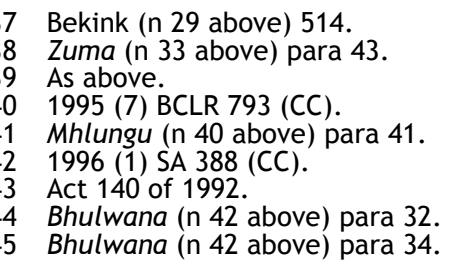


retrospectivity, at least with regard to legislation in place before the commencement of the Interim Constitution. When the Constitution was promulgated on 4 February 1997, the Constitution reversed this presumption in section 172(1)(b)(i). However, Woolman and Bishop argue that through the precedent set by O'Regan $\mathrm{J}$, the presumption against retrospectivity lives on and has extensively been followed by the courts (see paragraph 6.1 below). ${ }^{46}$

A case especially relevant in this regard is $S v N$ tsele, ${ }^{47}$ which also dealt with a reversed burden of proof concerning a provision of the Drugs and Drug Trafficking Act ${ }^{48}$ being declared constitutionally invalid. The crucial difference was that Ntsele was decided under the Constitution and not the Interim Constitution as Bhulwana was. Nonetheless Kriegler J quoted the Bhulwana judgment extensively as setting out the relevant factors that need to be taken into account when deciding the retrospective effect of a declaration of invalidity. ${ }^{49}$ This in spite of the fact that the constitutional texts are inherently different. The Constitution, as previously indicated, clearly has a different presumption than the Interim Constitution, namely a presumption in favour of retrospectivity instead of against retrospectivity, irrespective of the time of the legislation's inception.

The case of National Coalition for Gay and Lesbian Equality $v$ Minister of Justice ${ }^{50}$ concerned the common law crime and statutory crime of consensual sodomy being declared unconstitutional. ${ }^{51}$ This case is vital for three important reasons. The first is that Ackermann J clearly set out the differences between the Interim Constitution's and the Constitution's tests for the retrospectivity of declarations of invalidity (as explained at paragraph 3.1 above). ${ }^{52}$ Secondly the Court rationalised the Ntsele decision by stating that while the Bhulwana decision played an important weighing role in the test for retrospectivity, Kriegler $\mathrm{J}$ did not duplicate the test blindly, and that the tests for retrospectivity remained separate and markedly different under the Constitution and its predecessor. This was probably done, Ackermann $\mathrm{J}$ argues, because of the great similarity between the facts of the cases, both dealing with provisions in the same Act being declared unconstitutional. ${ }^{53}$ The Court found that the Constitution, in section 172(1)(b)(i), is clear in its assumption of retrospectivity pending an order to the contrary. Africa (2 $2^{\text {nd }}$ edition, OS, 2014) 146.

471997 (11) BCLR 1543 (CC).

48 Act 140 of 1992.

49 Ntsele (n 47 above) para 14

50 National Coalition (n 27 above).

51 National Coalition (n 27 above) para 1.

52 National Coalition (n 27 above) para 92.

53 National Coalition (n 27 above) para 93. 
Thirdly Ackermann J explained how the facts of National Coalition differ from the cases preceding it. The decisions in Bhulwana and Ntsele could not be given retrospective effect without great disruptions to the administration of justice, and prejudicing a prosecution who bona fide relied on the law as it appeared at such a time. However, in the present case before the Court, it would be 'grossly unjust and inequitable' to allow men who participated in consensual and private sodomy to remain in prison for a crime declared unconstitutional. ${ }^{54} \mathrm{~A}$ need for retrospectivity thus clearly existed. The Court continued and provided reasons for why unconditional retrospectivity was an unfit solution. The Court explained that certain persons convicted under the charge of sodomy could still, if the act had not been consensual, be found guilty of indecent assault. To allow unconditional retrospectivity could result in convictions being overturned without due judicial process being followed, and the release of persons from sentences who may still be guilty of rape, despite consensual sodomy as a crime being declared unconstitutional. The Court's solution to this delicate situation is to limit retrospective force to where a court of competent jurisdiction deems it 'just and equitable' to invalidate anything done by relying on the previous criminal definition of 'sodomy'. 55 It would be 'just and equitable' where the period for lodging an appeal has not yet expired. Where it has expired, a convicted person could bring an application for the condonation of such late lodging. This is to ensure the certainty of justice, through use of existing court structures. ${ }^{56}$

In Centre for Child Law $v$ Minister for Justice $e^{57}$ the constitutionality of the Criminal Law Amendment Act of $1997^{58}$ (new order legislation) and the application of section 172(1)(b)(i) of the Constitution was argued. The Criminal Law Amendment Act had made minimum sentences compulsory in cases concerning accused persons who were 16 or 17 years of age where courts previously had had more leniency in sentencing 16 and 17 year olds. The Court held that the amendment went against the constitutional 'principles of imprisonment as a last resort and for the shortest appropriate period of time' in the case of minors. ${ }^{59}$ As no distinction is made between old order and new order legislation in the Constitution, the Court's decision on the retrospectivity of the declaration was informed by section 172(1)(b)(i) of the Constitution, as in National Coalition. The applicants had specifically sought an order from the Court to assist minors who had previously been convicted under the provisions in 
question in having their cases reconsidered. ${ }^{60}$ The Court followed the example set in National Coalition and allowed retrospective force to the order insofar as it affected cases where an appeal was pending, could still timeously be brought, or could be condoned by the court. In addition, the Court directed the Minister for Justice and Constitutional Development, and the Minister for Correctional Services, respondents one and two in the case, to find and provide the number of cases so affected. ${ }^{61}$

It therefore becomes clear that a court is not in an enviable position, having to strike a delicate balance in terms of section $172(1)(b)(i)$, weighing up the individual rights of litigants who were prejudiced by law found to be invalid, and the administration of justice and good governance in an open and democratic society.

\section{The array of cases decided under section 10 of PEPUDA}

To fully appreciate the gravitas of the decision in Qwelane, one must have a sense of the quantity of cases decided on section 10 of PEPUDA, as well as the nature and extent of the orders given thereupon. Chapter 4 of PEPUDA ${ }^{62}$ does not so much create a new court or system of courts as it endows the existing courts with a new function, namely that of an equality court. ${ }^{63}$ This, however, does not mean that all magistrates and judges may hear disputes arising under PEPUDA; rather the intention is to create hearings where specially trained or experienced staff deal with equality disputes. ${ }^{64}$ The powers and functions of the equality court envisaged in PEPUDA are set out in section 21 and are wide-ranging. ${ }^{65}$ Various remedies may be combined to ensure effective relief to a successful complainant. ${ }^{66}$ Moreover the SAHRC has decided, negotiated and mediated many disputes in terms of the hate speech provision in PEPUDA and in terms of section 20(1)(f) of PEPUDA the SAHRC may institute proceedings in the equality court.

60 Centre for Child Law (n 57 above) para 72.

61 As above.

62 Sections $16-23$

63 Section 16(1)(a) of PEPUDA states that 'Every High Court is an equality court for the area of its jurisdiction' and section 16(1)(c) indicates that the Minister must, after consultation with the head of an administrative region defined in section 1 of the Magistrates' Courts Act, 1944 (Act 32 of 1944) assign the functions of an equality court to certain existing Magistrates' Courts (as indicated in subsubsections (i) to (v)).

64 Currie \& De Waal (n 3 above) 247.

65 Currie \& De Waal (n 3 above) 248, reference was also made hereto in Qwelane (n 1 above) para 10.

66 As above. 
The endeavour to discuss all of the cases flowing from the above would be a feat beyond the scope of our current analysis, especially in the light of the fact that many decisions based on section 10 were decided in the Magistrates' Courts and accordingly unreported. Yet a brief look at the eleven cases of the Magistrates' Courts that were readily available on the website of the Southern African Legal Institute under the decisions of the equality court, as well as seven of the most pertinent decisions of the reported High Court judgments, is illuminating. ${ }^{67}$ Of the Magistrates' Court cases considered, only one failed $^{68}$ and ten were successful in proving hate speech. 69 Of the seven High Court cases considered, four failed ${ }^{70}$ and three were successful. ${ }^{71}$ The nature of the remedies granted by the courts to successful complainants litigating on section 10 of PEPUDA are relevant to our analysis, as these remedies speak to the (possible) necessity of granting the declaration of invalidity retrospective force.

The ordering of apologies ${ }^{72}$ and the awarding of fairly minor damages ${ }^{73}$ were the preferred orders made by the Equality Court.

67 Available at http://www.saflii.org/za/cases/ZAEQC/ (accessed 31 March 2020).

68 Dube $v$ Weston EqC held at Durban Magistrates' Court (04/2006).

69 Strydom $v$ Black First Land First and Others EqC held at Johannesburg Magistrates' Court (11/2018); ANC v Sparrow EqC held at Scottburgh Magistrates' Court (01/2016); SAHRC $\vee$ Qwelane EqC held at Johannesburg Magistrates' Court (44/2011); Sonke Gender Justice v Malema EqC held at Johannesburg Magistrates' Court (02/2009); Maqudulela v Gotz EqC held at Port Shepstone Magistrates' Court (2009); Smith v Mgoqi and Mgoqi EqC held at Durban Magistrates' Court (60/2007); Magubane v Smith EqC held at Durban Magistrates' Court (01/2006); Donaldo v Haripersad EqC held at Durban Magistrates' Court (29/2005); Cacadu v Van Zyl EqC held at Victoria West Magistrates' Court (1/2005); Khoza $v$ Saeed and Essay EqC held at Durban Magistrates' Court (07/2005); Mdladla $\vee$ Smith EqC held at Durban Magistrates' Court (40/2005); ENM V KR EqC held at Durban Magistrates' Court (09/2004).

70 Gordhan v Malema and Another 2020 (1) SA 587 (GJ); Rarayi and Others v Oak Valley Estates and Others (EC13/2019) [2019] ZAEQC 7 (unreported judgment); South African National Editors' Forum and Others $v$ Economic Freedom Fighters and Another (90405/18) [2019] ZAEQC 6 (unreported judgment) and Manong and Associates (Pty) Ltd $\vee$ Eastern Cape Department of Roads and Transport \& Others (6) SA 589 (SCA).

71 Nelson Mandela Foundation Trust and Another $v$ Afriforum NPC and Others [2019] 4 All SA 237 (EqC); Afriforum and Another v Malema and Others 2011(6) SA 240 (EqC); South African Human Rights Commission obo South Africa Jewish Board of Deputies v Masuku and Another (EQ01/2012) [2012] ZAEQC.

72 Section 21(2)(j) of PEPUDA determines that an equality court may order an unconditional apology to remedy any of the violations catered for in the Act. Of the ten successful cases in the Magistrates' Court, only one was not ordered to apologise, and of the four successful matters in the High Court only one was ordered thereto.

73 PEPUDA in section 21 makes provision for two different monetary orders to remedy hate speech offences. The first is an order for the payment of any damages suffered in respect of any proven financial loss to the complainant for a wide variety of causes, including both patrimonial and non-patrimonial damages, and the second, more societal justice remedy, is the payment of an award to an appropriate body or organisation. In the cases where damages were awarded to the complainants, the smallest amount was awarded in 2005 at R 3000 , and the 
The wide powers of the equality court referred to above also enables the court to interdict certain conduct, ${ }^{74}$ where the breach of said interdict amounts to the common law crime of contempt of court ex facie curiae. ${ }^{75}$ These interdicts were present in four of the cases considered, ${ }^{76}$ the most notable (and notorious perhaps), the matters of Nelson Mandela Foundation Trust and Another $v$ Afriforum NPC and Others, ${ }^{77}$ also known as the 'Old flag' case, and Afriforum and Another $v$ Malema and Others, ${ }^{78}$ or the 'Shoot the Boer' case. It is, however, important to concede that the utterances of Mr Malema in the latter would probably still be regarded as hate speech under the revised wording by the Supreme Court of Appeal of section 10 of PEPUDA. ${ }^{79}$ Furthermore, the interdict barring the gratuitous display of the previous South African flag was founded not only on the hate speech provision of section 10 of PEPUDA, but also on grounds of unfair discrimination on the basis of race in terms of section 7 , as well as harassment based on section 11.80 Thus the interdict prohibiting the gratuitous display of the old flag would still stand even if the declaration of Qwelane was given retrospective force.

A matter worth mentioning is the conciliation agreement between the SAHRC and Ms Gretha Wiid. ${ }^{81}$ In this matter, although no reference was specifically made to section 10 of PEPUDA, the conduct of the respondent was labelled as hate speech. ${ }^{82}$ The respondent undertook, inter alia, to re-write the problematic areas of her book as well as not to raise the subject of homosexuality in her workshops. ${ }^{83}$ In other matters ${ }^{84}$ the SAHRC has decided cases based on section 10 of PEPUDA as well as the interpretations thereof by the equality court, and questioning the range of these decisions is perhaps a legitimate probe, but not the subject of discussion for current purposes.

largest sum in 2009 at R 20 000. Where damages were awarded to organisations, the amounts are significantly larger with the smallest sum being $R 50000$ awarded in 2010, and the largest R 150000 in 2016. Even Mr Qwelane was ordered in the trial court to pay damages to the SAHRC for his aggrieved statements in the amount of R 100000 in 2011.

74 Section 21(2)(f) of PEPUDA.

75 CR Snyman Strafreg (6 $6^{\text {th }}$ edition, LexisNexis, 2012) 346.

76 Nelson Mandela Foundation Trust and Another $v$ Afriforum NPC and Others [2019] 4 All SA 237 (EqC); Sparrow (n 69 above); Afriforum and Another v Malema and Others 2011(6) SA 240 (EqC) and Mdladla (n 69 above). Nelson Mandela Foundation (n 76 above).

78 Malema (n 76 above).

79 Qwelane (n 1 above) para 96.

80 Nelson Mandela Foundation (n 76 above) para 205; For an informative discussion on the merits of the case see the article by Herd (n 3 above) $130-154$

81 South African Human Rights Commission v Wiid Ref No: GP/1718/0052/BJ/KAC.

82 Wiid (n 81 above) para 5.2.3.

83 Wiid (n 81 above) para 6.1.4.

84 See for example 'Findings of the South African Human Rights Commission Regarding Certain Statements made by Mr Julius Malema and Another Member of the Economic Freedom Fighters, March 2019'. 
The issue already being alluded to is incidences where certain words, statements, utterances, or songs may have been interdicted on section 10 of PEPUDA, which was post facto found to be unconstitutional. This could create the undesired consequence of being found guilty of contempt of court if the interdicted phrase were uttered. Thus, a person could receive a criminal sanction stemming from an order based on a constitutionally invalid legal instrument.

It might be possible to argue that the previous defendants in these matters could also have argued that the section of PEPUDA is unconstitutional, as Mr Qwelane did. However, in terms of section 170 of the Constitution, Magistrates' Courts do not have the jurisdiction to inquire into or rule on the constitutionality of legislation. Although these defendants could theoretically have the matters transferred to the High Court, the cost implication thereof is significant and often insurmountable ${ }^{85}$ Furthermore, had this reasoning been followed in other matters of declarations of unconstitutionality, males convicted and imprisoned for consensual sexual acts of sodomy would have had to remain imprisoned, and child offenders would have had to continue serving significantly longer sentences, despite the Constitutional Court declaring the impugned legislation unconstitutional, in National Coalition $^{86}$ and Centre for Child Law, ${ }^{87}$ respectively.

\section{The injustice of limiting the retrospectivity in Qwelane}

Despite the Constitution creating a presumption in favour of retrospectivity, our courts seem reluctant to allow decisions to have retrospective force, as this proves disruptive to the administration of justice. In matters concerning freedom of expression, having a clear and tangible verdict on which speech is acceptable and which is not is paramount.

\subsection{A previous reluctancy to grant decisions retrospective force}

In Bhulwana, the court held that:

It is only when the interests of good government outweigh the interests of the individual litigants that the court will not grant relief to successful litigants [...] the litigants before the court should not be singled out for the grant of relief, but relief should be afforded to all

C Theophilopoulos et al Fundamental Principles of Civil Procedure (3rd edition, LexisNexis, 2015) 62.

86 National Coalition (n 27 above).

87 Centre for Child Law (n 57 above). 
people who are in the same situation as the litigants [...] [but the court should] be circumspect in exercising [its power in this regard]. ${ }^{88}$

This passage by O'Regan $\mathrm{J}$ has become the default approach of all the Superior Courts. In several cases the retrospectivity has been limited only to matters which are still sub judice. ${ }^{89}$ This in spite of the fact that the Constitution, which only came into operation after Bhulwana and with a significantly different wording than the Interim Constitution, clearly intended for retrospectivity to occur ex lege with the court awarded the authority only to limit the extent thereof, where such a limitation would be just and equitable.

The Constitutional Court in Estate Agency Affairs Board v Auction Alliance (Pty) Ltd and Others ${ }^{90}$ went so far as to say that there is a 'general rule favouring prospectivity' ${ }^{91}$ and quoted the earlier decision of itself in Mistry $v$ Interim Medical and Dental Council of South Africa. ${ }^{92}$ The latter is a matter decided under the Interim Constitution, whereas the former is a more recent decision under the Constitution. The Court acknowledges the difference between the two constitutions at paragraph 51, but then states that 'the general considerations that underlay it apply with equal force in this case. ${ }^{93}$ In this regard the authors can respectfully not agree with the notion that the text of the Constitution did not meaningfully change the legal position from the text of the Interim Constitution. The wording of the Constitution differs significantly, with a clear intention of granting declarations of unconstitutionality retrospective force automatically. Perhaps because the assumption is (or ought to be) that new order legislation would meet constitutional muster. Woolman argues that the continued application of the Bhulwana-test fails to appreciate the important differences in wording between the Constitution and its predecessor. ${ }^{94}$ The presumption that is created runs counter to the constitutional presumption in favour of retrospectivity and 'privileges non-interference in legal decisions above other concerns that go to justice and eq ${ }^{95}$ uity'.

South Africa is a constitutional democracy founded on the principles of constitutional supremacy, the rule of law, the principle of legality, legal certainty and enforceable fundamental rights. ${ }^{96}$ The 94; Engelbrecht $v$ RAF \& Another 2007 (6) SA 96 (CC) para 45; S v Mello 1998 (3) SA 712 (CC) para 13; Scagell \& Others v Attorney-General, Western Cape \& Others 1997 (2) SA 368 (CC) para 35-36; S v Mbata 1996 (2) SA 464 (CC) para 31; Brink v Kitshoff NO 1996 (4) SA 197 (CC) para 4.

902014 (3) SA 106 (CC).

91 Estate Agency Affairs Board (n 90 above) para 51 referring to para 44 of Mistry $v$ Interim Medical and Dental Council of South Africa 1998 (4) SA 1127 (CC).

92 Mistry (n 91 above).

93 Estate Agency Affairs Board (n 90 above) para 51.

94 Woolman (n 46 above) 146.

95 As above. 
authors would opine that it should be more difficult to disallow parties whose rights were infringed upon by unconstitutional legislation, to correct that infringement, and more so when the correction is constitutionally entrenched. The Constitution grants courts the authority to limit the retrospectivity only where it would be 'just and equitable'. ${ }^{97}$ This is certainly a broader and more flexible provision than the "interests of justice and good government" 98 constraint of the Interim Constitution. The latter, according to Ackermann J, only making out a part of the former. ${ }^{99}$

\subsection{The importance of retrospectivity in Qwelane}

It is important now to contextualise Qwelane within the development of our constitutional dispensation and how the matter distinguishes itself from the examples laid out above in paragraph 4. Firstly, the hate speech provision of section 10 of PEPUDA was promulgated and declared unconstitutional under the Constitution, and not its predecessor. PEPUDA is thus new order legislation and section 10 was accordingly objectively unconstitutional from the moment of its inception. ${ }^{100}$ Yet it took almost 20 years for the constitutional validity of it to be successfully questioned, with an abundance of controversial matters being decided thereupon.

As the assessment of case law under paragraph 5 above indicates, albeit somewhat limited in quantity, the monetary penalties faced by those contravening the hate speech provision were not exceptionally large. ${ }^{101}$ Moreover, the larger sums were usually paid to independent third parties, usually non-profit organisations labouring for some or other cause aiming to achieve social justice, and not the complainants. ${ }^{102}$ An argument could rightly be made that having these organisations repay the sums awarded to them, could neither be just nor equitable.

Having said that, one must appreciate that a verdict of hate speech bears the grunt of a highly stigmatised and heavy social burden, with respondents being judicially labelled racists, homophobes, sexists, etcetera, and wherein their thoughts, utterances, or ideas are declared legally unacceptable by the state. Whether or not the overturning of such a verdict could truly remedy the prejudice faced by the respondents wrongly found to have

96 Bekink (n 29 above) 117.

97 Section 172(1)(b)(i) of the Constitution, as explained at section 3.2 of this paper.

98 Section $98(6)$ of the Interim Constitution, as explained at section 3.2 of this paper.

99 National Coalition (n 27 above) para 94.

100 As explained at section 3.2 of this paper as well as in Currie \& De Waal (n 3 above) 400.

101 See section 5.2 of this paper.

102 As above. 
committed hate speech is uncertain, but the law surely ought to strive toward correcting a wrong, especially where the law itself is to blame. Likewise, there can be no legality in prosecuting a person for being in contempt of court by violating a court order founded on legislation that was later held to be unconstitutional and declared invalid. Thus, matters where respondents have been interdicted from expressing certain views surely ought to be overturned in light of the declaration of invalidity.

It is furthermore important to acknowledge that hate speech as a legal issue can never be separated from the fundamental right to freedom of expression, entrenched in section 16 of the Constitution. The importance of being allowed to express one's views freely is a right that can never be overemphasised. Dworkin argues that 'freedom of speech is valuable, not just in virtue of the consequence it has, but because it is an essential and "constitutive" feature of a just political society that government treat all its adults [...] as responsible moral agents'. ${ }^{103}$ Also, the Constitutional Court has acknowledged the importance of this right in several judgments ${ }^{104}$ and stated in South African National Defence Force Union v Minister of Defence ${ }^{105}$ that:

Freedom of expression lies at the heart of a democracy. It is valuable for many reasons, including its instrumental function as a guarantor of democracy, its implicit recognition and protection of the moral agency of individuals in our society and its facilitation of the search for truth by individuals and society generally. ${ }^{106}$

In $S \vee$ Mamabolo ${ }^{107}$ Kriegler $\mathrm{J}$ contextualised the importance of this right in context of our young democracy by stating:

Having regard to our recent past of thought control, censorship and enforced conformity to governmental theories, freedom of expression the free and open exchange of ideas - is no less important than it is in the United States of America. It could actually be contended with much force that the public interest in the open marketplace of ideas is all the more important to us in this country because our democracy is not yet firmly established and must feel its way. Therefore, we should be particularly astute to outlaw any form of thought control, however respectably dressed. ${ }^{108}$

These judgments, and several others, underpin the undeniable importance of freedom of expression in our post-apartheid South African society today. Notwithstanding the above, freedom of

103 Currie \& De Waal (n 3 above) 339 as referenced to R Dworkin Freedom's Law (1996) 200.

104 See in this regard also Banana $v$ Attorney-General 1999 (1) BCLR 27 (ZS) at 31F and Kauesa $v$ Minister of Home Affairs 1995 (11) BCLR 1540 (NmS) at 1554C.

1051999 (4) SA 469 (CC).

106 SANDF Union (n 105 above) para 7.

1072001 (3) SA 409 (CC).

108 Mamabolo (n 107 above) para 37. 
expression can never be absolute. In fact, a prominent addition to the Constitution, distinguishing itself from the Interim Constitution, is an internal limitation of the right to freedom of expression. ${ }^{109}$ The reality is that many forms of expression might not be palatable, but ought to be permissible in a democratic society. At paragraph 2 in casu the Court quoted Mokokoma Mokhonoana in stating that freedom of speech gives us the right to offend others, whereas freedom of thought gives them the choice whether or not to be offended. ${ }^{110}$ Yet, certain expression cannot be allowed and must be sanctionable. This remains true even for matters decided upon the impugned section 10 of PEPUDA. In this judgment the Supreme Court of Appeal has little more than asserted that the regulation of speech in terms of section 10 is impermissible. Where the line ought to be drawn between permissible and impermissible speech, now needs to be re-evaluated by the legislature and the courts, within the altered ambit of a different hate speech provision.

It is therefore important, we would argue, that the decision of Qwelane be granted retrospective force as it would be unjust and inequitable if such application is not granted to the matter. Previous complainants and respondents should be afforded the opportunity to have their cases re-evaluated in line with the now corrected stance regarding hate speech. In doing this, much needed clarity will be given to the true scope of freedom of expression, as it pertains to hate speech in South Africa.

\section{A possible special arrangement and matters pertaining thereto}

The Supreme Court of Appeal has been empowered in full by section 172(2) of the Constitution to declare legislation unconstitutional and invalid, subject to confirmation by the Constitutional Court, which it did in Qwelane.

In the case of Estate Agency Affairs Board v Auction Alliance (Pty) $L t d^{111}$ the Constitutional Court confirmed a declaration of unconstitutionality by the High Court, but further explained that section 172 of the Constitution also grants it the authority to alter the High Court's order on retrospectivity. ${ }^{112}$ It thus follows that the Constitutional Court in Qwelane will have the power not only to confirm or deny the declaration of invalidity, but if they confirm the order will have the authority to limit the retrospective force thereof.

109 Namely section 16(2) of the Constitution of the Republic of South Africa, 1996 see Currie \& De Waal (n 3 above) 338.

110 Qwelane (n 1 above) para 2.

111 Estate Agency Affairs Board (n 90 above).

112 Estate Agency Affairs Board (n 90 above) paras 45 - 51. 
In addition to the substantive factors, referred to in paragraph 5 above, that should be considered when deciding the retrospective effect of an order, it is apt to also examine certain practical questions pertaining to such a decision. This includes the question of whether an appeal or review process is more appropriate, as well as the awarding of costs where such a decision is taken upon appeal or review.

\subsection{To appeal or review, that is the question}

Two possibilities exist in procedural law for a person who seeks to have their case re-examined after a verdict has been handed down, namely the process of appeal or that of review. An appeal can be described as 'a rehearing on the merits but limited to the evidence or information on which the decision was given. The only question is then whether that decision is right or wrong'. ${ }^{113}$ A review on the other hand is the process by which a decision by the lower court is scrutinised by a High Court to detect any possible gross procedural irregularity or illegality. ${ }^{114}$

In casu, it is clear that we are dealing with an issue that does not neatly fit into either process. It is difficult to argue that the incorrect decision was reached on the merits of a particular case, where the very ground for unlawfulness or wrongfulness has now vanished, and in the light of the doctrine of objective invalidity never truly existed. Moreover, it is difficult to argue gross procedural irregularity as the complainant and presiding officer relied on the legislation in good faith.

The Constitutional Court has in the past dealt with the issue without much deliberation. The basic formula set out by O'Regan $J$ in Bhulwana, and subsequently extensively followed in limitations of retrospectivity, is to allow retrospectivity for cases where an appeal or review is still pending, as well as where an appeal could still (timeously) be lodged. ${ }^{115}$ The court has alluded to the possibility of aggrieved parties applying to have their late application for an appeal condoned. 116 There thus seemingly exists an assumption that the correct procedure would be one of appeal, probably as the merits of the case would have to be reconsidered, but that a review could be used for the same purpose, where a review of a case is pending. Perhaps problematic is the fact that both matters taken onto appeal or review have to be heard by a higher-ranking judicial body. Litigating in a court ranking higher than the court $a$ quo always means

113 DR Harms Law of South Africa Volume 4: Civil Procedure Superior Courts (2019) 771.

114 Harms (n 113 above) 711.

115 Bhulwana (n 42 above) para 34.

116 National Coalition (n 27 above) para 97. 
higher legal costs and often requires more manpower by way of judicial officers (be it by way of a full bench in the High Court or a bench consisting of at least three Supreme Court of Appeal judges). This whilst there is no true inherent reason why the trial court is unfit to hear the matter having simply relied on the legislation in a bona fide manner.

We therefore opine that the Constitutional Court, having an inherent power in terms of section 173 of the Constitution, could make a special judicial arrangement empowering the respective trial courts to re-evaluate the decisions taken by it in the light of the declaration of unconstitutionality and the wording substituted, where applicable. This, we would argue, would be the most cost effective and least disruptive manner to address the unfortunate predicament caused by the order of retrospectivity, whilst still allowing prejudiced parties the right to a fair and equitable justice system. Whether this offends deeper theoretical procedural law is an interesting question, but one that falls outside the scope of the current enquiry. Ours is primarily concerned with the extent of, and reasons for retrospectivity.

\subsection{Costs}

The Constitutional Court has in the past declined to formulate any comprehensive rules in respect of cost orders in constitutional litigation. ${ }^{117}$ Although the possible appeal against past decisions is not technically constitutional litigation, the legal foundation of such an appeal lies within the declaration of constitutional invalidity. To apply the general rule that costs should follow suit could very possibly result in parties who bona fide relied on the law as it stood at the time being unduly prejudiced, as the law on which they relied is no longer constitutionally valid. ${ }^{118}$ A legal system where persons could be discouraged from litigating on the law as it stands simply because such law may in future be declared unconstitutional, compromises the very legal certainty on which it was founded. On the other hand, it cannot be just and equitable to have a person ruled to have committed hate speech on constitutionally invalid legislation, be ordered to bear the costs of remedying that injustice.

The most equitable solution, although imperfect, would probably be to have each party carry their own costs, as no party can truly be faulted for the error of the legislature. This suggestion, however, pertains only to matters where the aggrieved party is successful in having a verdict of hate speech overturned. Where a court finds the

117 Ex Parte Gauteng Legislature: In re Gauteng School Education Bill 19951996 (3) SA 165 (CC).

118 National Coalition (n 27 above) para 95. 
utterance of a person to be hate speech even under the revised definition thereof, such a matter should surely be decided on its own merit and not by a rule-of-thumb.

\section{Conclusion}

More than two decades has passed since the enactment of the Interim Constitution, yet South African society is still grappling with the bounds and legal structures of our democracy. This process of continued review and revision of the basic laws and values of our land, and their implications, should not be seen as a symptom of instability, but rather of a living system of law, reflective of its democratic creators - the people.

Critical in this process, which we have largely entrusted onto our judiciary, is the ability to recognise that justice is not confined to the present and the future, but stretches even into the past. This principle is made tangible by the retrospective power the Constitution grants declarations of constitutional invalidity. Thus, our examination of the Qwelane judgment is done not only because of its singular importance, but also because it lucidly illustrates the broader challenge the court faces with regard to retrospectivity of declarations of invalidity.

Through an examination of case law it has been seen that, though our Constitution favours declarations of unconstitutionality having retrospective force, our courts have routinely and extensively limited the retrospectivity, following a precedent set under the Interim Constitution. This continued flawed application is a worrying trend. We hope that the Constitutional Court, provided the declaration is confirmed, will depart from this problematic habit of the judiciary. We have made suggestions as to how the Constitutional Court may limit the practical problems when deciding the retrospectivity of the declaration of unconstitutionality. At the very least, the unconstitutionality should have retrospective force in cases where certain expressions have been interdicted, in light of the constitutional importance of the right to freedom of expression.

Courts have a heavy burden and a powerful mandate. The administration of justice is rarely without hindrance, yet this should not deter courts from ensuring that justice remains uncompromised. 